\title{
О МЕДИЦИНСКОГ ГЕОГРАФИИ
}

\section{(в сеязи со статьей Н. П. Соколова в «Казанском медицинском журнале»,} 1961, № 3)

Многие считают, что медицинская география призвана лишь к изучению особенностей и закономерностей развития и распространения заболеваний, типичных лишь для определенных частей земного шара.

Между тем, природные факторы неотьемлемо связаны и с социальными моментами, ибо с повышением уровня благосостояния населения и с развитием медицинской науки исчезают (вернее, сводятся к минимуму) такие заболевания, которые в прошлом считались для этого края эндемичными.

Известно, что такие инфекционные заболевания, как чума, холера, оспа и проказа, в XVIII-XIX вв. были распространены в Европе и Азии.

В настоящее время в результате широких профилактических мер (вакцинация, санитарно-гигиенические мероприятия) случаев заболевания в Европе нет, а в эндемическом очаге в странах Азии они сведены к единицам.

Так, эндемическим очагом холеры с давних времен считают Индию. С развитием торговых отношений (XVI-XIX века) холера выходит за пределы этой страны и распространяется по всей Европе, унося с собой сотни и тысячи жителей городов и населенных пунктов.

Теперь, несмотря на существование широких торговых и промышленных отношений с Индией, случаи завоза и распространения холерной инфекции сведены к нулю.

Одновременно с улучшением жизненных условий в освобожденной от колониальной зависимости Индии и при соответствующих изменениях, происшедших в системе здравоохранения, заболеваемость холерой стала спорадическим явлением. Таким образом, прежнее представление о задачах медицинской географии должно быть пополнено. Сейчас одной из ее задач является выяснение вопроса о том, как географические условия влияют на степень распространения повсеместно встречающихя инфекшионных заболеваний. Ведь из практики известно, что дизентерия и брюшной тиф больше распространены в жарких краях, где имеется обилие фруктов, в то время как сыпной тиф чаще встречается в более холодных краях. Известно также, что переносчик малярии ниже $16^{\circ}$ не размножается, а яйца кишечных паразитов (аскариды) гибнут ниже $12^{\circ}$. В задачи медицинской географии следует включить систематическое изучение климатического фактора, который, бесспорно, является одной из первопричин характерных сдвигов в организме при акклиматизации (переезд жителя крайнего севера в южные края, из низменных местностей в высокогорные районы и наоборот и т. п.).

До последнего времени медико-географические исследования все еше проводятся географическими обществами: в СССР, как и во многих других странах, комиссией медицинской географии при географическом обшестве; в США же имеются отделения медицинской географии. Очевидно, по типу этих отделений Е. И. Игнатьев предлагаст создать «отделения на местах».

Не без основания Н. Б. Соколов в статье «Медицинская география, ее положение в научных обществах; определение ее содержания, методов и задач» отмечает, что: «устаревшим является предложение Е. И. Игнатьева, по существу ведущее к повторению пройденного этапа развития медицинской географии как самостоятельной дисциплины».

Необходимо признать, что по своему содержанию медицинская география более близка к медицине, чем $\mathrm{k}$ какой-либо отрасли географической науки, поскольку по своему содержанию медицинская география постоянно соприкасается с гигиеной и краевой патологией, теоретически и практически обосновывая мероприятия по охране здоровья населения в соответствии с географическими условиями.

П. С. Степанов (Тбилиси) 